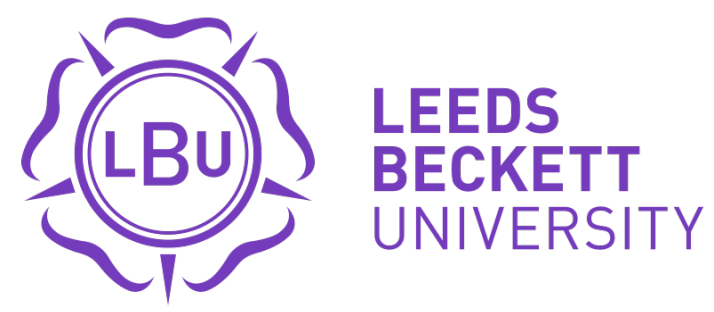

Citation:

Campbell, K and Demir, E and O'Reilly, MF (2019) Understanding conflict-related sexual violence and the 'everyday' experience of conflict through witness testimonies. Cooperation and Conflict, 54 (2). pp. 254-277. ISSN 0010-8367 DOI: https://doi.org/10.1177/0010836719838586

Link to Leeds Beckett Repository record:

https://eprints.leedsbeckett.ac.uk/id/eprint/5803/

Document Version:

Article (Accepted Version)

(C) The Author(s) 2019

The aim of the Leeds Beckett Repository is to provide open access to our research, as required by funder policies and permitted by publishers and copyright law.

The Leeds Beckett repository holds a wide range of publications, each of which has been checked for copyright and the relevant embargo period has been applied by the Research Services team.

We operate on a standard take-down policy. If you are the author or publisher of an output and you would like it removed from the repository, please contact us and we will investigate on a case-by-case basis.

Each thesis in the repository has been cleared where necessary by the author for third party copyright. If you would like a thesis to be removed from the repository or believe there is an issue with copyright, please contact us on openaccess@leedsbeckett.ac.uk and we will investigate on a case-by-case basis. 


\title{
Understanding conflict-related sexual violence and the 'everyday' experience of conflict through witness testimonies
}

\author{
Kirsten Campbell, Elma Demir and Maria O’Reilly
}

\begin{abstract}
The testimonies of witnesses who testify before criminal courts provide crucial insights into the situated experience of conflict-related sexual violence. Witness testimonies highlight the complex realities and everyday lives of individuals caught up in situations of armed conflict. The evidence presented by witnesses can provide vital insights into lived experiences of wartime violence, and reveal the seemingly mundane strategies and tactics adopted by victims to cope with, survive and resist the violent and coercive circumstances of war. This article foregrounds conflict-related sexual violence witness testimonies as highly significant sources of knowledge of everyday experiences of conflict. It sets out a bottom-up, mixed-method approach for identifying and analysing the experiential accounts of those who lived through conflict-related sexual violence, while engaging with the opportunities and challenges of using witness testimony. Our approach unsettles existing notions of 'the everyday' in Peace \& Conflict Studies as a synonym for narratives and practices of violence, justice and peacebuilding that are private, informal and largely hidden from view. Understanding witness testimonies requires conceptualising the everyday as an amalgam of formal and informal practices, as accessible through both elite and lay knowledges and as documented in both public and private (e.g. redacted) sources. It requires challenging taken-for-granted dichotomies that are frequently invoked to understand conflict and peace.
\end{abstract}

\section{Introduction}

Witness testimonies provide crucial insights into the situated experience of conflict-related sexual violence (CRSV). The testimonies of witnesses who appear before criminal courts offer a critical lens through which to understand lived experiences of war. Witness testimonies highlight the complex realities and everyday lives of individuals caught up in situations of armed conflict. They can provide an invaluable source of knowledge about gendered experiences of wartime violence, and the strategies and tactics adopted by victims of CRSV to cope with, survive and resist the violent and coercive circumstances of war.

Testimonies from criminal trials also hold vital information on the nature and quality of justice achieved through criminal prosecutions. Witness testimonies 
offer essential insights into the extent to which victims of human rights violations and violations of international humanitarian law achieve official recognition of these violations and redress for the harms incurred. Since they capture the day-to-day encounters and interactions in trial proceedings, witness testimonies can also provide crucial evidence on which to assess whether the legal process adequately acknowledges, or alternatively denies, complex experiences of victimisation and agency.

Despite their significance, the testimonies of witnesses to CRSV ${ }^{1}$ are neglected by existing studies of war, peacebuilding and post-war justice processes. This is surprising, as the concept of 'the everyday' is increasingly embraced by scholars within Peace \& Conflict Studies (PCS) to examine the lived experience of conflict and peace, particularly the small-scale strategies people use to navigate violence and peacebuilding in the context of their daily lives. The so-called 'local turn' in PCS scholarship (Mac Ginty and Richmond, 2013) has explored bottom-up, contextualised and day-to-day experiences of conflict and practices of peacebuilding, using concepts such as hybridity (McLeod, 2015a), agency (O'Reilly, 2017), friction (Björkdahl and Höglund, 2013) and the everyday (Mac Ginty, 2014). This scholarship has focused on how just and durable forms of peace may emerge via bottom-up rather than top-down practices, and by informal rather than formal actors (Lundy and McGovern, 2008; Mac Ginty, 2014). Yet, despite this move to incorporate non-elite knowledge into conflict analyses, studies of the 'everyday' dimensions of war and peace are often removed 'from the embodied world of those who experience violence, conflict and marginalisation on a daily basis' (Berents, 2015: 192), including victims and witnesses to CRSV.

In the field of transitional justice, meanwhile, feminist scholarship and activism has sought to obtain legal and social recognition of CRSV as serious crimes; challenge impunity by securing prosecutions of perpetrators and redress for victims; and secure reforms to ensure that survivors are not harmed by the adversarial legal process (Bell and O'Rourke, 2007: 26). Feminist efforts to provide a nuanced account of the gendered logic and impact of both war and post-war justice processes have focused on recovering narratives of CRSV and of the complex harms experienced by victims (for overviews, see Bell and O'Rourke, 2007; Buckley-Zistel and Stanley, 2012). By examining how CRSV survivors narrate such experiences - within diverse contexts such as research interviews (Baines and Stewart, 2011; Mischkowski and Mlinarević, 2009; Skjelsbæk, 2006), criminal trials (Houge, 2014; Kelsall and Stepakoff, 2007; Mertus, 2004; Mibenge, 2013; Mullins, 2009) and truth-telling mechanisms (Boesten, 2014; Crosby and Lykes, 2011; Leiby, 2009; Ross, 2003) - 
feminist studies have offered crucial insights into the impact of victimisation and the courageous efforts of CRSV survivors to (re)construct their lives and social identities as they navigate complex webs of social relationships, structures and norms (Skjelsbæk, 2006). This research has both highlighted and challenged conventional binaries of women as passive victims and of men as perpetrators of CRSV. By attending to gendered narratives and silences, feminist studies offer a fuller understanding of whether and how agency emerges in (post-)war contexts (Porter, 2016; Selimovic, 2018). Crucially, gender analyses of transitional justice open up space to consider 'agents, spaces, and processes of agency that may be hidden, ignored, or misrepresented' (Björkdahl and Selimovic, 2015: 166). Against this background, it is remarkable that CRSV witness testimonies located in transcripts of legal proceedings remain a significantly under-valued source of data on gendered, everyday experiences of conflict. This is unfortunate, as these testimonies can provide crucial insights into the lived experience of armed conflict and of CRSV, which can greatly expand our knowledge of these phenomena (Skjelsbæk, 2006).

This article engages with the significant opportunities and crucial challenges associated with using CRSV witness testimonies located in transcripts of legal proceedings. It introduces a methodology for systematically identifying, collecting and analysing this significantly under-valued source of data on everyday experiences of conflict. We argue that the situated accounts of witnesses to CRSV are an essential source for understanding the complex lived, embodied experiences of war. Understanding everyday experiences of war required us to undertake a bottom-up, contextualised, micro-level, qualitative approach to data collection and analysis, which we outline below. Our approach is informed by anthropological studies of war and political violence (Das, 2007; Nordstrom, 1997), and by feminist interventions in International Relations (IR) that have explored lived, embodied experiences of conflict (Parashar, 2013; Sylvester, 2010, 2013) and insecurity (McLeod, 2015b). These studies highlight that war and political violence cannot be fully understood without attending to the heterogenous narratives, personal experiences and everyday practices of situated individuals, particularly of women (Ackerly et al., 2006; O'Gorman, 2011). Feminist IR scholars have adopted unorthodox modes of inquiry - including discourse analysis (Hansen, 2006), narrative analysis (Wibben, 2011) and fieldwork interviews (D'Costa, 2006; McLeod, 2015b) - to explore marginalised voices and everyday experiences of war. We contribute to this scholarship by offering a bottom-up, mixed-method approach for accessing and analysing an important source of information about 'everyday' experiences of CRSV. 
This article offers a feminist intervention into 'everyday' peace and conflict research. It does so by directly engaging with the opportunities and challenges of using witness testimony - firstly, by setting out the challenges of, and strategies for, developing a methodology for identifying and analysing those accounts of CRSV, and, secondly, by showing how witness testimonies are highly significant sources of knowledge for understanding sexual violence and for reconceptualising 'the everyday' experience of conflict. Despite the 'kinship' between feminist and critical approaches to PCS (Björkdahl and Selimovic, 2015: 168), few studies have undertaken an explicitly feminist analysis of key concepts within critical PCS (McLeod, 2015a: 64). ${ }^{2}$ Moreover, contemporary studies on 'everyday peace' largely ignore feminist perspectives, despite feminist scholars such as Boulding (2000) and Ruddick (1980) contributing pioneering accounts of the significance of informal actors/institutions/interactions and the private realm for building peace (Vaittinen et al., 2019). This article provides a feminist critique of dominant understandings of 'the everyday' as a synonym for narratives and practices that are private, informal and largely hidden from view (Autesserre, 2014; Mac Ginty, 2013).

Understanding the experience of conflict from the standpoint of CRSV victims ultimately requires rethinking the very concept of the 'everyday', and challenging taken-for-granted dichotomies such as elite/lay, bottom-up/topdown, war/peace, public/private, formal/informal, exceptional/ordinary, victim/agent, which are frequently invoked to understand both violence and peace (see Åhäll, 2018). We show that accessing the lived experiences described within CRSV witness testimonies requires conceptualising 'the everyday' as an amalgam of formal and informal practices, accessible through both elite and lay knowledges and documented in both public and private (e.g. redacted) sources. Furthermore, our approach challenges dominant framings of CRSV as an exceptional form of violence perpetrated during the extraordinary circumstances of war (Baaz and Stern, 2018). In contrast, our approach understands acts of sexual violence as forming part of a broad spectrum of violence and coercion that victims experience day-to-day in conflict settings. These acts also vary in terms of frequency, severity, form and injury. Grasping the lived experiences of CRSV survivors therefore requires considering both socalled 'exceptional' and 'ordinary' forms of violence, while recognising that these categorisations are subjective, contextual and require a close reading of individual testimonies. We also show how the knowledge and documentation of the 'everyday' is itself constituted through a process of legal 'knowledge production' (Buss, 2014a: 88). To do this requires the rebuilding of the key concepts of agency and victimisation that have been central to understanding both the experience of CRSV and the 'everyday' in war and peace. 
The article first explores the significance of testimonies for building a deeper and richer understanding of experiences of CRSV from the position of victims. This provides the basis for our analysis of CRSV witness testimonies. This discussion also examines the benefits and challenges of using witness testimonies as sources of data on sexual violence in everyday experiences of conflict. The second section introduces our methodology, Mixed-Method Testimonial Analysis, and identifies key phases of research and methods deployed. This shows how Mixed-Method Testimonial Analysis can be deployed, firstly, to retrieve testimonies that are frequently overlooked, and, secondly, to analyse the situated knowledge enclosed within them. The third section illustrates the use of this methodology through the analysis of case transcripts. The article concludes by considering how building an understanding of CRSV from the position of victims complicates, and adds nuance to, existing conceptualisations of 'the everyday' within PCS. ${ }^{3}$

In this article we focus on our methodology for identifying and analysing CRSV victim testimony, drawing on examples from Prosecutor v. Mucić et al. (IT96-21) and Prosecutor v. Kvočka et al. (IT-98-31/1) cases, and the implications of these sources for conceptualising everyday conflict and peace. While our research focuses on testimonies from international war crimes prosecutions, our methodology can be adapted to analyse testimonies featuring in domestic prosecutions and/or informal justice mechanisms.

\section{The significance of witness testimonies for understanding conflict-related sexual violence and everyday experiences of conflict}

As of July 2017, some 4650 witnesses have appeared before the International Criminal Tribunal for the former Yugoslavia (ICTY), which has produced over 2.5 million pages of transcripts of its proceedings. ${ }^{4}$ The majority of witnesses appear as 'fact witnesses', and are called to give evidence to their experience of the crimes they lived through (Schoorl et al., 2016). Witness testimonies offer accounts of the experience of crimes of sexual violence, the context of those crimes and testimony about crimes committed by other people. As such, witness testimonies contained in transcripts can offer an invaluable and unique source of data about sexual violence and everyday experiences of conflict. While these accounts are necessarily partial and incomplete, they nevertheless include descriptions of the witness's experience of conflict as they saw, heard and felt it, providing a rich and detailed account of the events that they endured. These accounts begin with their first experience of the conflict, and unfold through descriptions of specific events. These also include descriptions of experiences that are significant to the witness in their recounting of these 
events. In comparison to the restrictive, technical and ostensibly neutral/objective language of trial judgements and indictments, victim testimonies often include rich, experiential and situated/subjective accounts of conflict. As such, they can offer a large and significant dataset of rich descriptions of war from the perspective of those who have experienced it.

Despite their importance, existing studies on CRSV tend to overlook these sources, focusing instead on evidence gathered from large-scale, populationbased surveys (Johnson et al., 2010; Swiss et al., 1998); reports from international commissions of enquiry, government agencies and human rights organisations; truth commission documents; and secondary sources (Cohen and Green, 2012; Cohen and Nordås, 2014; Leiby, 2009; Wood, 2006). CRSV witness testimonies are also surprisingly neglected by existing studies of post-war justice processes and war crimes trials. This is surprising, given the increasing importance given to witness testimony in the transitional justice and human rights fields (Alston and Knuckey, 2015; Gready, 2011).

While trial judgements have been considered as political and legal narratives at international and national levels (Hagan and Ivković, 2011; Zarkov and Glasius, 2014), there exist only limited studies of the trial transcripts of these proceedings. These include studies of narratives of prosecution and defence (Glasius, 2014; Meijers and Glasius, 2013), perpetrators (Houge, 2016; Skjelsbæk, 2015) and victim-witness testimony (Buss, 2014a; Dembour and Haslam, 2004). There are even fewer studies of sexual violence victimwitness testimony, which consist of studies of the International Criminal Tribunals for the former Yugoslavia and Rwanda (Campbell, 2002; Houge, 2014; Mertus, 2004; Mibenge, 2013; Mullins, 2009) and studies of truth commissions (Boesten, 2014; Leiby, 2009; Ross, 2003). Furthermore, studies of CRSV prosecutions largely focus on witness testimonies from singular rather than multiple legal cases (Kelsall and Stepakoff, 2007; Mertus, 2004; for exceptions see Campbell, 2007; Houge, 2014; Mullins, 2009); or else they examine extracts of testimonies cited in trial judgements or indictments, which are already 'partially acknowledged, though not analyzed as evidence of gender-based persecution, by the prosecutor and the trial chambers' (Mibenge, 2013: 86).

Finally, as noted above, the testimonies of CRSV witnesses are also overlooked by studies of conflict and peacebuilding. The lived experiences of women who are situated at 'the epicentres of political violence' are frequently written out of scholarly accounts, which 'focus primarily on the military, the political, the institutional, and the masculine in addressing political violence' 
(Nordstrom, 2005: 402). Survivors' account can provide crucial insights into the embodied experience of CRSV and its ongoing impact on their everyday lives (Skjelsbæk, 2006). As a significant source of information about the experience of CRSV, witness testimonies can address this significant gap in current research.

Given that $48 \%$ of the accused appearing before the ICTY have charges of sexual violence included in the indictments, the ICTY transcripts provide a significant source of CRSV testimonies. ${ }^{5}$ Some 600 female witnesses have appeared before the ICTY, with the majority appearing in CRSV cases (Schoorl et al., 2016: 123). ${ }^{6}$ There are also significant numbers of male sexual violence witnesses (Campbell, 2007; Mischkowski and Mlinarević, 2009). While acknowledging that protective measures, recalled witnesses or resubmitted witness statements impact upon available accounts, nevertheless ICTY transcripts represent a significant source of information concerning CRSV.

Witness testimonies as sources for understanding CRSV and everyday experiences of conflict

Our approach bridges the divide within feminist IR (Caprioli, 2004) between positivist, quantitative research designs that examine patterns of perpetration of CRSV via statistical analysis and hypothesis testing (e.g. Cohen and Nordås, 2014; Leiby, 2009) and interpretivist, qualitative research designs that build knowledge from the everyday experiences of CRSV victims and witnesses (D'Costa, 2006; Mookherjee, 2015; Ross, 2003). The generation of large-scale, generalised, macro-level, quantitative data on CRSV has many advantages. It can provide the basis for an assessment of the nature, magnitude, patterns and impact of CRSV. However, aggregated data provides a partial picture of the reality of CRSV. For example, it cannot account for the complex and varied experience of these events as described by victims themselves. Furthermore, a top-down approach to data collection and analysis struggles to identify and analyse the small-scale, micro-level tactics and strategies of agency and resistance deployed in response to experiences of victimisation.

To more fully understand CRSV requires including the lived, everyday experience of those who lived through such events. This involves undertaking a bottom-up, contextualised, micro-level, qualitative approach to data collection and analysis. However, this is an ethically and politically sensitive area, in which survivors face ongoing demands for disclosure. ${ }^{7}$ To avoid this problem of 'overresearching', our strategy is to use these testimonies as resources while building in a reflexive process of consultation with advocacy groups, practitioners and 
other key informants (Campbell, 2018). While important for contextualising such experiences, judgements and indictments typically offer limited accounts of sexual violence. Testimonies, by comparison, can provide richer accounts of these crimes, and so can offer meaningful and socially contextualised information about CRSV that is grounded in lived experience.

This approach also confers upon witnesses to CRSV the epistemic authority to provide accounts of CRSV that they and others experienced. ${ }^{8}$ Testifying in the courtroom involves the witness actively producing accounts of her experience of CRSV. Giving epistemic authority to witnesses resists the presumption that the court only exercises repressive power over witness testimony, which reduces witness testimony to given legal scripts. Rather, witnesses also testify to the events as they saw them and experienced them. The ICTY itself acknowledges this aspect of testimony: 'the evidence she gave was the way she, as the person who endured these events, saw them happen' (Furundzija Judgement, 10 December 1998: para.116). She acts as 'a witness to the truth of what happens during an event' (Laub, 1992: 80). Witness testimonies include accounts not only of the experience of crimes of sexual violence, but also of their experiences of conflict as the witness saw it happen.

Building on this strategy, our transcript methodology uses the victim's accounts of experiences of these crimes to build a fuller and more accurate understanding of sexual violence in the context of conflict. Because we are concerned to capture more than each individual account, our methodology examines patterns of these crimes as described by the victims across the set of all witness testimonies. This approach aggregates each of these distinct forms of experience described within each witness testimony, using them to move past individual to collective descriptions of CRSV.

Significantly, our feminist methodology utilises a gender perspective on conflict, offering an alternative frame for building a fuller understanding of everyday experiences of conflict. We follow Doris Buss (2014a: 88) in treating these testimonies as another important source of knowledge about women's experiences of conflict. In the case of the ICTY, women disproportionately appear as witnesses in sexual violence cases, and hence are an important source of this knowledge. For this reason, these testimonies can provide an invaluable lens through which to see women's experiences of the Yugoslav conflicts, given that women and girls tell a 'different war story' (Nordstrom, 1997). This includes their experience of being 'targets' of, and participants in, conflict. 
Importantly, this approach gives a richer understanding of the experience of CRSV, placing this experience of sexual violence in the broader context of conflict (such as the ethnic cleansing of a village or take-over of a town), and thereby illuminating how CRSV is situated within the broader experience of conflict. Importantly also, these witnesses testify to events other than sexual violence, not least of which because women are often the only survivors of those events (Campbell, 2002). They testify to other acts of violence committed against them, and committed against others, providing key evidence regarding events leading up to the armed conflict in their region; other crimes committed against their communities or ethnic groups by the perpetrators; the forces present in their region, the chains of command of these forces, and the identity and position of perpetrators (Brammertz and Jarvis, 2016: 124).

Because these transcripts also include testimonies about male sexual violence, this approach can also displace the common gendered patterns of who are victims and agents in war, in which men testify to their experience of war, and women to their experience of rape (Campbell, 2002). Accordingly, these witness testimonies can provide the basis for building a fuller account of the role of gender in shaping experiences of conflict, and the gendered nature of conflict itself.

The challenges of using witness testimonies as sources for understanding CRSV and everyday experiences of conflict

However, testimony is dialogically produced, and the ways in which a witness describes her experience is structured by the ideological and institutional context of testimony and by the relations of power in which the witness is imbricated (McNay, 2000: 113-115). Witness testimony offers accounts of the experience of CRSV within the structured framework of criminal proceedings. Witnesses are selected because of their experience of particular crimes, and their testimony is used to provide evidence of these crimes. Our methodology recognises that witness testimonies are shaped by the legal process, and that this legal shaping of their accounts must be understood in order to understand the context in which witnesses testify to their experiences of conflict.

This approach acknowledges the politics of the legal production of witness accounts of CRSV, and so addresses the issue that the production of these accounts by law is not neutral, but reflects everyday practices of power in the courtroom itself. These everyday practices produce what Julie Mertus (2004) calls the 'legal counter-narrative', the process through which the Prosecution chops her (victim-witness) narrative into parts and reconstructs it 
as evidence of the perpetrator's actions and her subject position as Victim, while the Defence also subjects that narrative to continual contestation and calls into question her claim to be the victim of the crime. For example, in our methodology we examine how the witness is able - or not - to present this account of the experience of sexual violence, and of its conflict context. This analysis focuses on two key categories of interactions in the legal proceedings. The first category records interventions in testimony, where judicial actors interrupt or intervene in the account that the witness is giving, and incomplete evidence, where the witness is prevented from finishing their account. For example, Witness J in Kvočka did not experience any interventions in her testimony in examination-in-chief, but was prevented from providing complete answers to questions in cross-examination. The second key category concerns challenges to witness evidence, such as credibility, reliability or corroboration. For example, Witness $J$ in Kvočka was challenged on the grounds of inconsistency between her testimony and prior statements. This analysis of interactions in legal proceedings is combined with an analysis of the evidential form and function of the evidence, such as which party the witness appears for, whether the witness is asked to provide evidence of crimes against themselves or others and whether the witness appears under protective measures, or gives evidence live before the court or by video link. For example, Witness J in Kvočka was first given limited protection measures, but then requests and is granted full protective measures.

It is crucial to recognise that what Mertus describes as the 'legal counternarrative' of the trial proceedings is also shaped by the type of crimes alleged against the accused and the judicial determination of facts, law and guilt. For this reason, testimonies need to be read in the context of the other legal materials, that is, the indictment and the judgement, in order to capture the wider experience of justice. This is because the indictment 'names' those harms that the witness describes in legal terms, and structures the evidential function of the witness testimony. For example, the accused Radic was charged as a direct perpetrator of sexual assaults of Witness J with rape as a crime against humanity, while the accused Kvočka was charged as a participant in the joint criminal enterprise of persecutions as a crime against humanity. Witness J testified to her rape and sexual assault (to establish the charge of rape), as well as Kvočka's position as deputy commander of the camp (to establish his participation in the criminal enterprise to commit these persecutions). Equally important is the verdict on these charges, which is delivered in trial and appeal judgements, as these name the harms that will be recognised as crimes in the public domain, and determine the responsibility of the accused for those crimes. So, for example, while both Radić and Kvočka were convicted at trial for 
their crimes against Witness J, Kvočka's conviction was overturned on appeal on the grounds that there was insufficient evidence to establish that he was present in Omarska when these crimes were committed. Charges in the indictment will shape what aspects of the sexual violence experience the prosecution will focus upon, and the characterisation of persuasive evidence in judgements will shape whether the court accepts that that experience has been legally established. As such, transcript analysis needs to integrate the legal shaping of the experience of justice.

This legal shaping of witness testimony is not only evident in the form and content of individual accounts of the experience of CRSV, but also in which accounts become part of the public record. Only certain accounts of the experiences of war are included in public judgements, and not all transcripts of witness testimonies become publicly available. Protective measures, recalling witnesses or resubmitting witness statements within and across cases are legal processes that shape which and how witness accounts of their experiences become public. These are gendered legal processes. In the ICTY, women constitute a comparatively small number of the total number of witnesses, and hence produce proportionately smaller numbers of witness testimonies. Moreover, because women predominantly appear as sexual violence witnesses, they are more likely to have their testimony given in a session that is closed to the public, and hence appears as 'redacted' or removed from the public records of the court. Accordingly, transcript analysis also needs to capture the legal shaping of this public record.

For these reasons, individual testimonies cannot be treated as 'data' by themselves. Rather, witness testimony also needs to be read contextually in relation to its shaping by the legal process. Our methodology aims to both capture these rich witness accounts and also address the specific features of transcripts as data sources. For example, this methodology captures all accounts of CRSV presented by the defence, prosecution and court, but ensures that they are differentiated as sources. Accordingly, we situate witness testimonies within the legal process and use a mixed-method approach to testimonial analysis to identify and analyse descriptions of the experience of CRSV both within individual witness testimonies and across the set of all witness testimonies.

\section{Mixed-Method Testimonial Analysis: Methods and phases of research}

Our Mixed-Method Testimonial Analysis provides a comprehensive methodology for retrieving and analysing sexual violence in everyday 
experiences of conflict. Our approach of collecting both numerical/quantitative and descriptive/qualitative forms of data allows us to capture the rich descriptions, and complexity, of the experience of sexual violence, while also identifying statistical patterns of perpetration and patterns of prosecution at an aggregate level. The extensive amount of material available in transcripts and the complexity of our data collection and analysis required a phased approach to testimonial analysis.

\section{Challenge one: Identifying CRSV cases - Phase I}

The first challenge was to classify each legal case as either a CRSV case or a nonCRSV case. A CRSV case is a legal case that includes an allegation of sexual violence. Sexual violence is defined as any act of sexual coercion committed in circumstances of armed conflict in the territory of the former Yugoslavia between 1991 and 2001. The term 'allegation' indicates a statement or claim of fact that describes sexual violence. Allegations may be made at any stage of legal proceedings, and can be found in indictments; transcripts of trial proceedings; and judgements. Where an allegation of sexual violence is found in any of these legal materials, the case in question is classified as a CRSV case.

To manage the vast corpus of legal documents, a 'triage' process was developed to identify all cases featuring sexual violence allegations. Firstly, CRSV cases were provisionally identified via a review of the leading publication on the prosecution of CRSV at the ICTY (Brammertz and Jarvis, 2016). ${ }^{9}$ Secondly, cutting-edge text mining techniques were applied to the indictments, transcripts and judgements of cases not provisionally identified as CRSV cases. QDA Miner was deployed to search for allegations of sexual violence using key terms and phrases listed in our bespoke CRSV Lexicon. All cases containing positive results (e.g. containing a sexual violence allegation) were recategorised as a CRSV case and subjected to detailed analysis. A total of 53 out of 64 cases were identified as CRSV cases using this approach, 11 more than identified by Brammertz and Jarvis (2016). Thirdly, the confirmed, final indictments of all remaining cases were reviewed, and any containing sexual violence allegations were reclassified as CRSV cases. Figure 1 shows how legal cases were filtered via this triage process to produce a set of CRSV cases. 


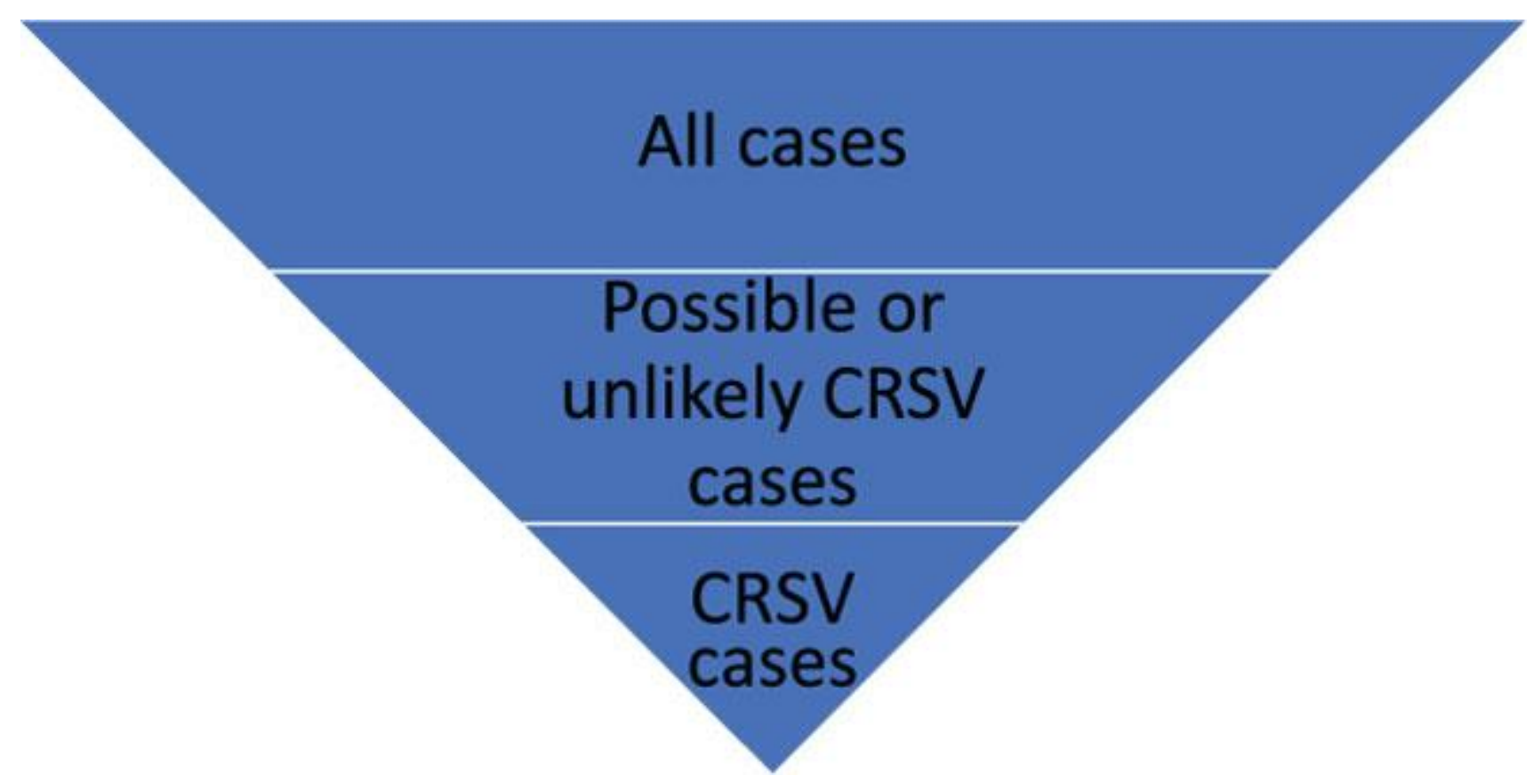

Figure 1. Triage process for identifying conflict-related sexual violence (CRSV) cases.

Our CRSV Lexicon was constructed using key terms and phrases relating to CRSV (Table 1). These search terms therefore encompass not only precise descriptions of sexual and other forms of violence, but also capture the broader 'cultural scaffolding' that makes CRSV possible (Gavey, 2005). Key terms and phrases were identified, firstly, via review of secondary literature analysing CRSV and its prosecution and, secondly, via close analysis of four individual witness testimonies. ${ }^{10}$

Table 1.

Conflict-related sexual violence (CRSV) Lexicon categories and examples.

\begin{tabular}{|ll|}
\hline Category of key words and phrases & Examples \\
\hline Rape and sexual violence & Rape \\
Sexualised body parts & Sexual violence; sex crime \\
& Anal \\
Reproduction & Penis \\
& Vagina \\
Clothing & Abortion \\
& Birth control \\
General violence and harassment & Bra \\
& Knickers \\
& Abuse \\
& Assault
\end{tabular}




\begin{tabular}{|ll|}
\hline Category of key words and phrases & Examples \\
\hline Sexual acts & Blow job \\
& Sex act \\
\hline Broader sexuality and romance & Intimate \\
& Sexuality \\
Agency, choice and coercion & Non-consensual \\
Cultural terms denoting causes and consequences of CRSV & Ashamed \\
\hline
\end{tabular}

\section{Challenge two: Identifying individual CRSV witness testimonies - Phase II}

The second challenge was to systematically identify individual witness testimonies containing allegations of CRSV from the large corpus of trial transcripts from CRSV cases. To do this, we deployed text mining in Phase II. Transcripts of daily trial proceedings are digitised and available at the ICTY's website. These record several distinct phases of trial proceedings, of which only oral and written testimonies containing CRSV allegations are required for our analysis. Phase II entailed identifying and isolating individual CRSV witness testimonies that are not redacted or held in closed session, by separating these from other phases of trial proceedings.

\section{Challenge three: Analysing individual CRSV witness testimonies - Phase III}

The third challenge was how to analyse individual witness testimonies to capture key dimensions of CRSV as experienced by the victim, including the following: data on the frequency of CRSV; socio-demographic information on perpetrators and victims; and information on the nature of CRSV perpetrated, as situated in time and space, etc. To develop a coding schema that captured these elements, we draw on the 'Who Did What to Whom Model' of events analysis, by disaggregating the 'grammar' of sexual violence (Ball, 1996; Ball et al., 2000) in terms of acts experienced by individual victims where possible (as we outline in our final section).

To understand the situated experience of CRSV victims, we developed the concept of a 'CRSV Event'. This concept indicates a unique set of sexual violence incidents as they are experienced by the victim, with each incident referring to one distinct act of sexual violence directly perpetrated by one person against one victim. This recognises that the same individual victim may experience multiple acts of sexual violence, by multiple perpetrators, in multiple settings. The concept of a 'CRSV Event' therefore connects those incidents that are experienced by the same individual victim. Our approach allows us to capture individual witness accounts of their experiences, while also situating their experiences in the broader conflict context. As we detail below, CRSV is 
captured through the coding of the descriptions of a victim's experience of sexual violence that is embedded within the everyday experience of conflict given in witness testimonies.

Focusing upon the sexual violence experience of victims in testimonies also enables us to examine how the accounts of these experiences appear in trial proceedings, and to examine the legal shaping of these accounts. This analysis of transcripts is intertwined with the analysis of judgements and indictments. A description of the analysis of judgements and indictments in these cases is not given here as it goes beyond the scope of this article. While indictments and judgements show the development and application of legal norms, testimonies show how these legal norms shape these accounts. Besides connecting the use of the same evidence across different legal cases, certain 'legal' variables have been developed for transcripts utilised to map the different evidential uses of testimony. This analysis enables a comparison of who gives evidence of what, and how that evidence is presented and evaluated by the court. Equally importantly, it analyses the capture of these accounts by legal norms, such as whether they appear in transcripts but not in judgements and indictments, or are not accepted as evidential proof of the acts alleged in the final verdict on the guilt of the accused. For this reason, the third phase combines qualitative content analysis of legal materials, with quantitative analysis of coded SV incidents, to generate our CRSV Dataset.

\section{Challenge four: Scope of dataset, biases and limitations}

Our overall project dataset is built from the indictments, judgements and transcripts of all completed CRSV cases prosecuted before the ICTY between 1994 and 2016. This analysis of the everyday experience of conflict and courts in testimonies provides a rich and large dataset of descriptions of everyday experiences of CRSV. Our analysis does not claim to provide a representative sample of 'the primary victim' population in the war. Such a positivist approach would be misplaced, given that no such 'victim population' existed or can be meaningfully established. The most comprehensive investigation of CRSV allegations during the conflict by the United Nations (UN) Commission of Experts, finished before the war ended, had limited regional scope and victim numbers. It is impossible, over two decades after the conflict ended, to estimate incidence, prevalence or total number of victims. Moreover, a positivist model does not attend to the social construction of 'victim populations'. It cannot account for the situated and changing meaning of concepts such as sexual violence, or that identities (such as ethnicity) are constituted (partly) through conflict. Accordingly, no positivist model can allow 
us to achieve a 'representative' sample of a given population, and in any event, studies of sexual violence in domestic jurisdictions have shown that this approach itself has significant limitations in revealing the incidence and frequency of sexual violence in population-based studies (Walby et al., 2017).

The data generated through our mixed-method testimonial analysis should be regarded as meaningful and significant because the dataset of descriptions of CRSV can be said to capture the experiences of those 'most affected' by CRSV in the Yugoslav wars. The large number of testimonies from male and female witnesses and victims provide an incomplete but meaningful data source about CRSV 'in virtually every geographical area during the conflicts [and] in numerous conflict-related settings' (Brammertz and Jarvis, 2016). Following this inclusive approach, we code all allegations of CRSV in all testimonies, and do not sample these sources (Leiby, 2011) or use secondary reports summarised in nongovernmental organisation (NGO) or state documents (Cohen and Nordås, 2014). We also acknowledge the important social construction of the 'sexual violence experience' - through the use of our CRSV lexicon and strategies for limiting coding bias (such as inter-coder reliability testing); documentation of our coding process and decisions in a codebook; consultation with key informants (to draw attention to bias); and comparison with secondary sources (e.g. UN Expert Commission) to identify inaccuracy. In this way, the methodology addresses typically identified issues of 'bias' in reporting of CRSV, including the following: (a) under-reporting by victims (who may be unable or unwilling to report); (b) institutional focus on certain victim categories (such as male or female victims); (c) over-reporting by conflicting parties/NGOs; and (d) biases in the coding process (Cohen and Nordås, 2014).

\section{The situated experience of the conflict-related sexual violence victim}

The next section illustrates how this transcript analysis can be used to illuminate CRSV in the everyday experience of conflict. It does so through the case study of two sexual violence cases heard before the ICTY - Prosecutor $v$. Mucić et al. (IT-96-21) and Prosecutor v. Kvočka et al. (IT-98-31/1). We have chosen these cases for three key reasons. Firstly, while both cases involve CRSV perpetrated in contexts of detention, they reflect two different crime bases (that is, particular sets of criminal acts) and geographical areas - Konjic and Prijedor. Secondly, the cases chosen include testimonies to CRSV perpetrated against both female and male victims. Thirdly, these cases encompass testimonies of victim-witnesses who testify to CRSV both with (Kvočka) and without (Mucić) protective measures. 


\section{Capturing CRSV in the everyday experience of conflict}

To capture the complex patterns of CRSV in everyday experiences of conflict, we focus on the victim's experience. This experience is profoundly shaped by gender, with men and women experiencing different patterns of 'who did what to whom' (Campbell, 2007; Wood, 2014). We still know surprisingly little about these experiences of war (Buss, 2014b). Much of the literature on CRSV treats sexual violence as an 'exceptional experience', which is removed both from its peacetime context of 'normal' violence against women and its wartime context of the wider gendered dynamics of organised violence (Ní Aoláin et al., 2011: 46).

Our approach instead seeks to understand CRSV as a gendered experience that is situated within the wider experience of conflict. The concept of 'experience' refers to the witness's description of facts or events, rather than the witness's perception, subjectivity or sense of self. It derives from the social situatedness of that experience, insofar as the experience is produced by social actions, organisations and structures. Accordingly, 'CRSV experience' refers to the experience of sexual violence from the standpoint or position of the victim. It is an epistemological, not ontological, concept. Joan Scott (1992: 25) reminds us that 'we need to attend to the historical [and social] processes that ... position subjects and produce their experiences'. We examine how the experience of CRSV is shaped by complex gendered patterns of social practices (repeated social actions) and social organisation (existing social norms and structures). Accordingly, we understand patterns of CRSV experiences as different forms of practices of gender-based harms, involving multiple actors (victims and perpetrators), that are repeated across the differentiated time and space of the conflict. With this approach we hope to take the 'first step required in future studies of sexual violence in conflict-affected situations [which] is to bring gender analysis in as a multifaceted form of explanation focused on structures, institutions and identities' (Davies and True, 2015: 8).

These experiences of CRSV are coded in the testimonies through key coding categories. These enable the identification of the elements of the description of the sexual violence experience of the victim, as illustrated below using the testimony of Witness J in the Kvočka case (Kvočka Transcript, 5 September 2000). The first key coding category is the 'pre-sexual violence course of events', which is the sequence of events that happens to the victim before the first incident of sexual violence, and that are related to the sexual violence incident. These events may range from arrest to deportation. So, for example, Witness J provides an extensive description of her experience of 'ethnic 
cleansing' in Prijedor, and transfer to the Omarska camp. She describes how an 'interrogation' is an integral part of this experience of sexual violence. The second key coding category is 'the elements of sexual violence'. These are the disaggregated elements of 'who did what to whom', in which each incident of sexual violence against each individual victim is identified in the testimony. These are coded in terms of characteristics, such as form (e.g. what type of sexual violence), setting (e.g. camp, police station, refugee column), accompanying forms of violence (e.g. physical or mental violence) and conflict context (e.g. paramilitary attack, camp). For example, Witness J describes multiple incidences of rape and attempted rape of herself and others by single and multiple perpetrators while she was detained in the Omarska camp. The third key category is the 'post-sexual violence course of events', which includes descriptions of the direct effects of the incidents upon the victim (such as pregnancy or psychological trauma), as well as what happens to the victim after the final incident (such as escape or death). For example, Witness I describes her release from Omarska camp and return to Prijedor before being forced to leave the town.

\section{The challenge of conceptualising agentic social actions in CRSV and the everyday experience of conflict}

An integral challenge of this analysis of the witness's description of the experiences of self or of others of CRSV is how to capture the social practices of coercion and agency that construct that experience. Building on Connell (1997: 118), we argue that it is necessary to develop a concept of agency in the everyday context of conflict as the exercise of self-determination and resistance deployed by a CRSV victim. There is a danger that focusing on experiences of victimisation will render invisible the active strategies and tactics deployed by victims to cope with, survive and resist the violence and coercion they experienced (Kelly, 2013). A fuller exploration of a victim's experience of CRSV requires accounting for patterns of violent and coercive behaviour deployed by perpetrators to exert power and domination, while also describing the victim's efforts to (re)assert power and control over the situation of herself and others. Victimisation and agency are not dichotomous (Mahoney, 1994), but rather coexist within the CRSV experience of the victim.

To understand how agency is fostered and deployed, or alternatively thwarted and suppressed, this analysis builds upon O'Reilly's (2017) conceptualisation of 'gendered agency in war and peace'. Agency involves the capacity to critically reflect upon one's desires, choices, and situation, and to adopt appropriate decisions and actions (see Friedman, 2003). 
This capacity is social in nature; it is influenced by the temporal and sociocultural context and web of relationships (familial, institutional, etc.) in which an agent is embedded (Mackenzie and Stoljar, 2000; Meyers, 1989). The ability to demonstrate agency is therefore enhanced or alternatively impaired by interpersonal relationships, material structures and inequalities of power (Showden, 2011).

In contexts of armed conflict, agency can be detected in the decision of a CRSV survivor to report her experience of victimisation. It is also present in the actions taken by others to provide formal or informal support to a victim, to end violence and/or improve her own or other's situation. Rather than identifying as agentic only selective forms of behaviour - for example, disclosure to relevant authorities or testifying in court (Mahoney, 1994) - our understanding of agency encompasses a wide spectrum of acts and decisions whose character ranges from passive to active forms (Kabeer, 2005: 15).

Passive modes of agency are demonstrated when acts and decisions are taken in the context of restricted choices (Kabeer, 2005: 15). Milojka Antićs efforts to placate Čelebići camp guards, by obeying direct commands and coercive rules, is one example. It is important to stress, however, that she lacked realistic options for challenging the violent and coercive circumstances in which she was being held. ${ }^{11}$ In contrast, active modes of agency materialise in circumstances where an agent can select purposefully from a range of choices (Kabeer, 2005: 15). Ms Antić's refusal of protective measures and the act of testifying publicly in open sessions is one example of active agency (see Mucić Transcript, 3 April 1997: 1760). The testimonies also provide examples of active agency that challenge damaging and/or unequal societal values and norms, and so may be described as being transformative in character (Kabeer, 2005: 15). In conflict and post-conflict contexts, the act of testifying may work to challenge patriarchal legal norms and practices, which assume that CRSV is productive of shame or stigma. ${ }^{12}$

The challenge of conceptualising coercive circumstances and social actions in CRSV and the everyday experience of conflict

To build a fuller conceptualisation of the experiences of CRSV requires placing acts of sexual violence within a continuum of violent and coercive conduct. We argue that it is necessary to develop a concept of 'coercive circumstances' that addresses the context or environment of coercion that shapes the everyday experience of conflict from the position of the victim. This concept aims to capture the wide circumstances that circumscribe the victim's capacity for 
action and autonomy in conflict. These circumstances include the existence of armed conflict, such as an armed attack or combat situation, the presence of military or armed persons, forms of duress such as threat, intimidation, violence or abuse of power, and particular situations, such as a genocidal campaign or detention. These circumstances all constitute practices of coercion that constrain the witness's capacity to freely determine their actions. ${ }^{13}$

Accordingly, we view CRSV as a part of a broad spectrum of violence, which varies in terms of frequency, severity, form and level of injury inflicted (see e.g. Walby, 2007). Acts of sexual violence are often integral elements of a strategy initiated to achieve domination and control over the victim. Discrete acts of CRSV often form part of a wider pattern of 'coercive control' that features other forms of physical and verbal abuse (Stark, 2009). CRSV can be viewed, following Walby (2007: 13), as part of a 'coercive "course of conduct", a series of related occurrences, rather than a one-off event, which engenders fear between the acts of physical violence themselves'. ${ }^{14}$ Understanding the everyday experience of conflict from the perspective of CRSV survivors therefore means attending to the wide range of violence, domination and subordination experienced in wartime - ranging from physical violence (e.g. rape, torture), through verbal threats and abuse, to structural violence (e.g. starvation, material deprivation). It also entails a consideration of relationships, firstly, of violence and, secondly, of power.

Following Foucault (1982: 220), a relationship of violence is one that 'acts upon a body or upon things; it forces, it bends, it destroys or it closes off all possibilities'. The exercise of violence works to extinguish resistance and is productive of passivity in the individual over which violence is exerted. In the context of wartime detention, Milojka Antić had no choice but to comply with demands of her captors to ensure her survival. Ms Antić's detention in Čelebići involved almost complete subjection to the will of armed men who held her captive. In contrast, a power relationship opens up, 'a whole field of responses, reactions, results, and possible inventions', since it entails recognition of the subjectivity of the Other over whom power is wielded (Foucault, 1982: 220). Power relations are agonistic and involve negotiation and resistance. One example is when Milojka Antić acts to negotiate the conditions of her release from Čelebići with camp commander, Zdravko Mucić, managing to expand her freedom of movement so that it encompassed her home village (Mucić Transcript, 3 April 1997: 1815). Another example is when she thwarts a potential act of sexual violence by a lower-ranking guard by threatening to call for help and alert the deputy commander, Hazim Delić (Mucić Transcript, 3 April 1997: 1802). 
Foucault's (1979) notion of disciplinary power is also particularly relevant to understanding the everyday experience of conflict. Ms Antićs testimony points to the use of surveillance practices in daily life both inside and outside of detention, as parties to the conflict sought to establish and retain control over a territory and its population. In the weeks prior to her detention, she describes how her village was searched by armed men in camouflage uniforms, while she and others were temporarily detained by neighbours, and men from her village were arrested and held in detention (Mucić Transcript, 3 April 1997: 17611770). After she too was detained, the forms of surveillance she experienced intensified, with her captors placing severe limits on her ability to move, speak, eat and perform other bodily and social functions in everyday life. ${ }^{15} \mathrm{Ms}$ Antić's body - its appearance, cleanliness, comportment and movements - was rendered 'docile' (Foucault, 1979: 138) through disciplinary techniques that carefully controlled her actions and position. ${ }^{16}$

Overall, the coercive circumstances of armed conflict - and in this example, of detention - frequently involve situations in which an individual is subjected to violence and domination, where their capacity for agency is quashed or suppressed. At other times, they are caught in asymmetrical yet ever-shifting power relations, opening possibilities for taking decisions and actions of selfdetermination and resistance and/or allowing some element of control to be regained. Capturing the experience of CRSV requires building concepts that describe not only the violent and coercive behaviour of perpetrators, but also the agentic acts that victims deploy to cope with, survive and resist such violence. We agree that the everyday experience of conflict may present opportunities for agency to be expressed. Yet, we caution that it is important to recognise that violence and coercion are also integral (and frequently debilitating) features of the everyday experience of CRSV. As such, a fuller account of the 'everyday' experiences of conflict requires building new concepts of agency and victimisation.

\section{Concluding discussion}

Scholars, policymakers and activists stress the importance of documenting the nature, magnitude, patterns and impact of sexual violence in conflict. Yet, CRSV remains a highly 'elusive phenomenon' (Roth et al., 2011: 22). There remains a need to develop research methodologies that can capture the complex and varying dynamics of CRSV across time and space. Orthodox approaches, which rely on quantitative instruments (such as large-scale population-based surveys) to produce knowledge about CRSV, may present an incomplete picture. These analyses tend to use 'top-down', externally defined measures, constructed by 
elite actors who are often located outside the conflict context. The lived reality of CRSV as an embodied, situated experience and its complex relationship to conflict tend to be either obscured or made 'hypervisible' (Buss, 2009) by traditional methods of recording and analysing these crimes.

This article has highlighted the value of undertaking a bottom-up, mixedmethod approach to collecting and analysing CRSV testimonies. It has argued that witness testimonies provide crucial insights into the everyday dimensions of CRSV. Our Mixed-Method Testimonial Analysis is designed to capture the unprecedented volume and complexity of data available on CRSV and justice processes, while also attending to the nuances of the lived experiences of CRSV victims. Our unique lexicon of CRSV search terms provides the basis on which to systematically identify incidents of CRSV from a large corpus of legal materials. Qualitative and quantitative analysis of CRSV incidents captures key dimensions of CRSV and draws on events analysis to disaggregate the 'grammar' of sexual violence (Ball, 1996) as experienced by individual victims.

Significantly, our methodology situates CRSV crimes not only within the dynamics of armed conflict but also within the realm of everyday experience. Everyday life and the ways in which individuals and communities daily navigate situations of armed conflict are crucial for understanding the context of CRSV. Our analysis contributes to debates on the 'local turn' in PCS, by outlining a bottom-up methodology that analyses the situated experience of conflict from the standpoint of those who lived through it. Yet, our engagement with witness testimonies complicates, and adds nuance to, dominant understandings of 'the everyday' as a synonym for narratives and practices of violence, justice and peacebuilding that are largely private, informal and hidden from view. This article demonstrates the importance of acknowledging that 'the everyday' operates as a combination of formal and informal practices; as retrievable through both elite and lay knowledges; and as recorded in both public and private sources. Our analysis of CRSV testimonies also reveals the broad spectrum of violence and coercion that victims experience on a daily basis in conflict settings. This underscores the importance of attending to both 'exceptional' and 'ordinary' forms of violence that are recounted in individual witness testimonies. Understanding CRSV also means placing acts of sexual violence within a continuum of violent and coercive conduct that spans 'public' and 'private' spheres and 'wartime' and 'peacetime' settings. This requires, firstly, moving analysis beyond single violations to encompass the broader spectrum of harms experienced by victims and, secondly, unpacking gender norms and structures of power that hold some degree of continuity across war and peace. Comprehending the everyday experience of conflict from the 
position of CRSV victims requires unsettling clear distinctions between war/peace, public/private, formal/informal, elite/lay, exceptional/ordinary, victim/agent and other dichotomies that are frequently (re)produced to explain contemporary forms of violence and practices of peacebuilding. Ultimately, our engagement with CRSV witness testimonies has required us to reconceptualise 'the everyday'.

\section{Acknowledgments}

Please note that authors are listed in alphabetical order. This article was produced through joint authorship of all three authors. The authors would like to thank Jasenka Ferizović, Gorana Mlinarević and Marina Veličković for helpful comments on earlier drafts.

\section{Funding}

The research leading to these results has received funding from the European Research Council under the European Union's Seventh Framework Programme (FP/2007-2013)/ERC Grant Agreement no. 313626. Maria O'Reilly's research was also supported by a PaCCS Innovation Award from the Arts and Humanities Research Council [grant number AH/N00848/1].

\section{Notes}

1.By testimonies of witnesses to CRSV, we refer throughout this article to oral testimonies to CRSV (whether to self or to other(s)) given by witnesses in criminal trials. Our analysis focuses on the specific challenges of working with these sources of evidence, which are significantly shaped by the legal process in which they are produced. We therefore exclude other forms of CRSV witness testimony (e.g. witness statements provided to truth commissions, women's courts and tribunals). For examples of the variety of testimonies relating specifically to gendered experiences of wars fought in the former Yugoslavia, see Björkdahl and Selimovic (2018).

2.Exceptions include Björkdahl and Selimovic (2015), McLeod (2015a) and Partis-Jennings (2017).

3. The article is part of a wider project that maps patterns of CRSV perpetrated during the armed conflicts in the former Yugoslavia, and identifies patterns of CRSV prosecutions before the International Criminal Tribunal for the former Yugoslavia ('ICTY') and the domestic courts of Bosnia and Herzegovina ('BiH'). A longer work by the authors will provide an analysis of findings from across all 
CRSV cases heard before ICTY. For reasons of space, we focus here on our methodology for identifying and analysing victim testimony.

4. Please see facts and figures published by ICTY available at: http://www.icty.org/en/content/infographic-icty-facts-figures (accessed 28 July 2017).

5. Please see facts and figures published by ICTY available at:http://www.icty.org/en/features/crimes-sexual-violence/innumbers (accessed 28 July 2017).

6. Please see facts and figures published by ICTY available at: http://www.icty.org/en/about/registry/witnesses/statistics (accessed 28 July 2017).

7.For an overview of the ethical challenges of researching CRSV and strategies for ethical accountability, see Campbell (2017).

8.On notions of epistemic authority and epistemic privilege, and their connection to feminist standpoint theory, see Janack (1997).

9.Annex B of Brammertz and Jarvis (2016) sets out charges relating to sexual violence in ICTY cases. All the cases listed in the Annex were provisionally classified as CRSV cases.

10. This sample was chosen to include witnesses testifying to CRSV to themselves and witnesses testifying to CRSV to others, as well as testimonies to CRSV perpetrated against female (Mucić and Kunarac) and male victims (Mucić and Tadić).

11.Milojka Antić recounts being forced to comply with the orders of Hazim Delić who perpetrated multiple acts of sexual violence against her in highly coercive circumstances. See Mucić Transcript, 3 April 1997: 1777-1778, 1784, 1800.

12. The decision not to testify in criminal trials may also represent an assertion of agency by victims. For a discussion of the relationship between gender, agency and voice/silence, see Selimovic (2018).

13. This concept builds upon the legal doctrine of 'coercive conditions', first described in The Prosecutor v. Akayesu, ICTR-96-4-T, Judgement, Trial Chamber, 2 September 1998. 
14.Stark (2009) and Walby (2007) focus on domestic violence and violence against women in 'peacetime' contexts. Their insights are useful for understanding CRSV.

15.For example, Ms Antić recounts how she and other detainees were not allowed to talk. See Mucić Transcript, 3 April 1997: 1797.

16.For example, Ms Antić was ordered to bathe by Hazim Delić, under a guard's close supervision, before being raped. See Mucić Transcript, 3 April 1997: 1782-1785.

\section{References}

Ackerly B, Stern M and True J (eds) (2006) Feminist Methodologies for International Relations. Cambridge: Cambridge University Press.

Åhäll L (2018) Feeling Everyday IR: Embodied, affective, militarising movement as choreography of war. Cooperation and

Conflict, https://doi.org/10.1177/0010836718807501.

Alston P and Knuckey S (eds) (2015) The Transformation of Human Rights FactFinding. Oxford: Oxford University Press.

Autesserre S (2014) Peaceland: Conflict Resolution and the Everyday Politics of International Intervention. Cambridge: Cambridge University Press.

Baaz ME and Stern M (2018) Curious erasures: The sexual in wartime sexual violence. International Feminist Journal of Politics 20: 295-314.

Baines E and Stewart B (2011) 'I cannot accept what I have not done': Storytelling, gender and transitional justice. Journal of Human Rights Practice 3(3): 245-263.

Ball P (1996) Who Did What to Whom?: Planning and Implementing a Large Scale Human Rights Data Project. Washington, DC: American Association for the Advancement of Science.

Ball P, Spirer H and Spirer L (2000) Making the Case: Investigating Large Scale Human Rights Violations Using Information Systems and Data Analysis. Washington, DC: American Association for the Advancement of Science.

Bell C and O'Rourke C (2007) Does feminism need a theory of transitional justice? An introductory essay. International Journal of Transitional Justice 1(1): 23-44. 
Berents $H$ (2015) An embodied everyday peace in the midst of violence. Peacebuilding 3(2): 186-199.

Björkdahl A and Höglund K (2013) Precarious peacebuilding: Friction in globallocal encounters. Peacebuilding 1(3): 289-299.

Björkdahl A and Selimovic JM (2015) Gendering agency in transitional justice. Security Dialogue 46(2): 165-182.

Björkdahl A and Selimovic JM (2018) Feminist ethnographic research:

Excavating narratives of wartime rape. In: Millar $\mathrm{G}$ (ed.) Ethnographic Peace Research. Basingstoke: Palgrave Macmillan, pp. 43-64.

Boesten J (2014) Sexual Violence during War and Peace: Gender, Power, and Post-Conflict Justice in Peru. Basingstoke: Palgrave Macmillan.

Boulding E (2000) Cultures of Peace: The Hidden Side of History. Syracuse, NY: Syracuse University Press.

Brammertz S and Jarvis M (eds) (2016) Prosecuting Conflict-Related Sexual Violence. Oxford: Oxford University Press.

Buckley- Zistel S and Stanley R (eds) (2012) Gender in Transitional Justice. Basingstoke: Palgrave Macmillan.

Buss D (2009) Rethinking 'rape as a weapon of war'. Feminist Legal Studies 17(2): 145-163.

Buss D (2014a) Knowing women: Translating patriarchy in international criminal law. Social \& Legal Studies 23(1): 73-92.

Buss D (2014b) Seeing sexual violence in conflict and post-conflict societies: The limits of visibility. In: Buss D, Lebert J, Rutherford B, et al. (eds) Sexual Violence in Conflict and Post-Conflict Societies: International Agendas and African Contexts. New York and London: Routledge, pp. 3-27.

Campbell K (2002) Legal memories: Sexual assault, memory, and international humanitarian law. Signs: Journal of Women in Culture and Society 28(1): 149178.

Campbell K (2007) The gender of transitional justice: Law, sexual violence and the International Criminal Tribunal for the Former Yugoslavia. The International Journal of Transitional Justice 1(3): 411-432.

Campbell K (2017) Ethical challenges: Researching war crimes. In: Cowburn M, Gelsthorpe L and Wahidin A (eds) Research Ethics in Criminology: Dilemmas, Issues and Solutions. Abingdon: Routledge, pp. 150165. 
Campbell K (2018) Producing knowledge in the field of sexual violence in armed conflict research: Objects, methods, politics, and gender justice methodology. Social Politics 25(4): 469-495.

Caprioli M (2004) Feminist IR theory and quantitative methodology: A critical analysis. International Studies Review 6(2): 253-269.

Cohen DK and Green AH (2012) Dueling incentives: Sexual violence in Liberia and the politics of human rights advocacy. Journal of Peace Research 49(3): 445-458.

Cohen DK and Nordås R (2014) Sexual violence in armed conflict: Introducing the CRSVAC dataset, 1989-2009. Journal of Peace Research 51(3): 418-428.

Connell P (1997) Understanding victimization and agency: Considerations of race, class and gender. PoLAR: Political and Legal Anthropology Review 20(2): 115-143.

Crosby A and Lykes MB (2011) Mayan women survivors speak: The gendered relations of truth telling in Postwar Guatemala. International Journal of Transitional Justice 5(3): 456-476.

Das V (2007) Life and Words: Violence and the Descent into the Ordinary. Berkeley: University of California Press.

Davies S and True J (2015) Reframing conflict-related sexual and gender-based violence: Bringing gender analysis back. Security Dialogue 46(6): 495-512.

D'Costa B (2006) Marginalized identity: New frontiers in research for IR? In: Ackerly B, Stern M and True J (eds) Feminist Methodologies for International Relations. Cambridge: Cambridge University Press, pp. 129-152.

Dembour M and Haslam E (2004) Silencing hearings? Victim-witnesses at war crimes trials. European Journal of International Law 15(1): 151-177.

Foucault M (1979) Discipline and Punish. New York: Vintage Books.

Foucault M (1982) Afterword: The subject and power.

In: Dreyfus $\mathrm{H}$ and Rabinow P (eds) Michel Foucault: Beyond Structuralism and Hermeneutics. Hemel Hempstead: Harvester Wheatsheaf, pp. 220-221.

Friedman M (2003) Autonomy, Gender, Politics. Oxford: Oxford University Press.

Gavey N (2005) Just Sex? The Cultural Scaffolding of Rape. London: Routledge. Glasius M (2014) Terror, terrorizing, terrorism: Instilling fear as a crime in the cases of Radovan Karadzic and Charles Taylor. 
In: Zarkov D and Glasius M (eds) Narratives of Justice In and Out of the Courtroom. Cham: Springer International Publishing, pp. 45-61.

Gready P (2011) The Era of Transitional Justice: The Aftermath of the South Africa Truth and Reconciliation Commission and beyond. Oxford and New York: Routledge.

Hagan J and Ivković SK (2011) Reclaiming Justice. New York: Oxford University Press.

Hansen L (2006) Security as Practice: Discourse Analysis and the Bosnian War. Oxon and New York: Routledge.

Houge A (2014) Sexualized war violence: Subversive victimization and ignored perpetrators. In: Lander I, Ryan S and Jon N (eds) Masculinities in the Criminological Field: Control, Vulnerability, and Risk-Taking. Farnham: Ashgate, pp. 165-183.

Houge A (2016) Re-presentations of defendant perpetrators in sexual war violence cases before international and military criminal courts. British Journal of Criminology 56(3): 419-437.

Janack M (1997) Standpoint epistemology without the 'standpoint'?: An examination of epistemic privilege and epistemic authority. Hypatia 12(2): 125139.

Johnson K, Scott J, Rughita B, et al. (2010) Association of sexual violence and human rights violations with physical and mental health in territories of the Eastern Democratic Republic of the Congo. Journal of the American Medical Association 304(5): 553-562.

Kabeer N (2005) Gender equality and women's empowerment: A critical analysis of the third millennium development goal. Gender \& Development 13(1): 13-24.

Kelly L (2013) Surviving Sexual Violence. Hoboken, NJ: John Wiley \& Sons. Kelsall MS and Stepakoff S (2007) 'When we wanted to talk about rape': Silencing sexual violence at the Special Court for Sierra Leone. The International Journal of Transitional Justice 1(3): 355-374.

Laub D (1992) An Event without Witness: Truth, Testimony and Survival. In Felman S and Laub D (ed) Testimony: Crises of Witnessing in Literature, Psychoanalysis, and History. New York: Routledge, pp.75-92

Leiby ML (2009) Wartime sexual violence in Guatemala and Peru. International Studies Quarterly 53(2): 445-468. 
Leiby M (2011) State-perpetrated Wartime Sexual Violence in Latin America. PhD Dissertation, Albuquerque: University of New Mexico

Lundy P and McGovern M (2008) Whose justice? Rethinking transitional justice from the bottom up. Journal of Law and Society 35(2): 265-292.

Mac Ginty R (2013) Introduction: The transcripts of peace: Public, hidden or non-obvious? Journal of Intervention and Statebuilding 7(3): 423-430.

Mac Ginty R (2014) Everyday peace: Bottom-up and local agency in conflictaffected societies. Security Dialogue 45(6): 548-564.

Mac Ginty R and Richmond O (2013) The local turn in peace building: A critical agenda for peace. Third World Quarterly 34(5): 763-783.

Mackenzie C and Stoljar N (eds) (2000) Relational Autonomy: Feminist Perspectives on Autonomy, Agency, and the Social Self. New York: Oxford University Press.

Mahoney MR (1994) Victimization or oppression? Women's lives, violence, and agency. In: Fineman $\mathrm{M}$ and Mykitiuk R (eds) The public nature of private violence: The discovery of domestic abuse. New York: Routledge, pp.59-92.

McLeod L (2015a) Feminist approach to hybridity: Understanding local and international interactions in producing post-conflict gender security. Journal of Intervention and Statebuilding 9(1): 48-69.

McLeod L (2015b) Gender Politics and Security Discourse: Personal-Political Imaginations and Feminism in 'Post-Conflict' Serbia. Abingdon: Routledge.

McNay L (2000) Gender and Agency: Reconfiguring the Subject in Feminist and Social Theory. Cambridge: Polity Press.

Meijers T and Glasius M (2013) Expression of justice or political trial?: Discursive battles in the Karadžić case. Human Rights Quarterly 35(3): 720-752.

Mertus J (2004) Shouting from the bottom of the well: The impact of international trials for wartime rape on women's agency. International Feminist Journal of Politics 6(1): 110-128.

Meyers DT (1989) Self, Society, and Personal Choice. New York: Columbia University Press.

Mibenge CS (2013) Sex and International Tribunals: The Erasure of Gender from the War Narrative. Philadelphia: University of Pennsylvania Press.

Mischkowski G and Mlinarević G (2009) The Trouble with Rape Trials - Views of Witnesses, Prosecutors and Judges on Prosecuting Sexualised Violence during 
the War in the Former Yugoslavia. Cologne: Medica Mondiale e.V. Available at: https://www.medicamondiale.org/fileadmin/redaktion/5_Service/Mediathek /Dokumente/English/Documentations_studies/medica_mondiale_and_that_it_ does_not_happen_to_anyone_anywhere_in_the_world_english_complete_ver sion_dec_2009.pdf (accessed 25 March 2019).

Mookherjee N (2015) The Spectral Wound: Sexual Violence, Public Memories, and the Bangladesh War of 1971. Durham, NC: Duke University Press.

Mullins C (2009) 'We are going to rape you and taste Tutsi women': Rape during the 1994 Rwandan Genocide. The British Journal of Criminology 49(6): 719-735.

Ní Aoláin F, Haynes D and Cahn N (2011) On the Frontlines: Gender, War, and the Post-Conflict Process. New York: Oxford University Press.

Nordstrom C (1997) A Different Kind of War Story. Philadelphia: University of Pennsylvania Press.

Nordstrom C (2005) (Gendered) war. Studies in Conflict \& Terrorism 28(5): 399411.

O'Gorman E (2011) The Front Line Runs through Every Woman: Women \& Local Resistance in the Zimbabwean Liberation War. Suffolk: Boydell \& Brewer Ltd.

O'Reilly M (2017) Gendered Agency in War and Peace: Gender Justice and Women's Activism in Post-Conflict Bosnia-Herzegovina. Basingstoke: Palgrave Macmillan.

Parashar S (2013) What wars and 'war bodies' know about international relations. Cambridge Review of International Affairs 26(4): 615-630.

Partis-Jennings $H$ (2017) The (in) security of gender in Afghanistan's peacebuilding project: Hybridity and affect. International Feminist Journal of Politics 19(4): 411-425.

Porter E (2016) Gendered narratives: Stories and silences in transitional justice. Human Rights Review 17(1): 35-50.

Ross F (2003) Bearing Witness: Women and the Truth and Reconciliation Commission in South Africa. London: Pluto Press.

Roth F, Guberek T and Green AH (2011) Using Quantitative Data to Assess Conflict-Related Sexual Violence in Colombia: Challenges and Opportunities. Bogotá: Corporación Punto de Vista \& Benetech Technology Serving Humanity.

Ruddick S (1980) Maternal thinking. Feminist Studies 6(2): 342-367. 
Scott J (1992) Experience. In: Butler J and Scott J (eds) Feminists Theorize the Political. New York: Routledge, pp. 22-40.

Selimovic JS (2018) Gendered silences in post-conflict societies: A typology. Peacebuilding. Epub ahead of print 30 July. DOI: 10.1080/21647259.2018.1491681.

Schoorl HV, King KL, Rubert S, de Smit T, and Meernik JD (2016) Echoes of Testimonies: A Pilot Study into the Long-term Impact of Bearing Witness before the ICTY. The Hague: University of North Texas and the International Criminal Tribunal for the Former Yugoslavia (joint publication). Accessed March 25, 2019. http://www.icty.org/x/file/About/Reg istry/Witnesses/Echoes-FullReport_EN.pdf.

Showden CR (2011) Choices Women Make: Agency in Domestic Violence, Assisted Reproduction, and Sex Work. Minneapolis: University of Minnesota Press.

Skjelsbæk I (2006) Victim and survivor: Narrated social identities of women who experienced rape during the war in Bosnia-Herzegovina. Feminism \& Psychology 16(4): 373-403.

Skjelsbæk I (2015) The military perpetrator: A narrative analysis of sentencing judgments on sexual violence offenders at the International Criminal Tribunal for the Former Yugoslavia (ICTY). Journal of Social and Political Psychology 3(1): 46-70.

Stark E (2009) Coercive Control: The Entrapment of Women in Personal Life. Oxford: Oxford University Press.

Swiss S, Jennings PJ, Aryee GV, et al. (1998) Violence against women during the Liberian civil conflict. Journal of the American Medical Association 279(8): 625629.

Sylvester C (ed.) (2010) Experiencing War. Abingdon: Routledge.

Sylvester C (ed.) (2013) War as Experience: Contributions from International Relations and Feminist Analysis. London: Routledge.

Vaittinen V, Donahoe A, Kunz R, Ómarsdóttir SB, and Roohi S (2019) Care as everyday peacebuilding. Peacebuilding 7(3): 10.1080/21647259.2019.1588453

Walby S (2007) Indicators to measure violence against women. In: Working Paper № 1, Prepared for the Expert Group Meeting on indicators to measure violence against women, organized by the United Nations Division for the 
Advancement of Women, UNECE and UNSD, in collaboration with ECLAC, ESCWA, ESCAP, and ECA, Geneva, 8-10 October 2007.

Walby S, Towers J, Balderston S, et al. (2017) The Concept and Measurement of Violence against Women and Men. Bristol: Policy Press.

Wibben AT (2011) Feminist Security Studies: A Narrative Approach. Abingdon: Routledge.

Wood EJ (2006) Variation in sexual violence during war. Politics \& Society 34(3): 307-342.

Wood EJ (2014) Conflict-related sexual violence and the policy implications of recent research. The International Review of the Red Cross 96(894): 457-478.

Zarkov D and Glasius M (eds) (2014) Narratives of Justice in and Out of the Courtroom: Former Yugoslavia and beyond. London: Springer.

\section{Cases Cited}

The Prosecutor v. Furundzija Case No.: IT-95-17/1-T, Judgement, Trial Chamber. 10 December 1998. Available at http://www.icty.org/x/cases/furundzija/tjug/en/fur-tj981210e.pdf (accessed 25 March 2019).

The Prosecutor v. Mucić Case No.: IT-96-21, Transcript, Trial Chamber. 3 April 1997: 1759-1817. Available at http://www.icty.org/case/mucic/4 (accessed 25 March 2019).

The Prosecutor v. Kvočka et al. Case No.: IT-98-30/1, Transcript, Trial Chamber. 5 September 2000: 4720-4797. Available at http://www.icty.org/case/kvocka/4 (accessed 25 March 2019). 